MARóTI Dávid

PhD-hallgató

NKE ÁNTK
DOI: 10.15170/DIKE.2021.05.01.15

\title{
Egy új, mégis régi Németország születése
}

\section{The Birth of a New but Old Germany}

The year 1945 brought a radical change in the German history. The total defeat landed the Reich in difficulty. On the territory of the German Reich four entities have been established which could only get in touch with each other if the Allied Powers allowed them. The Allies took over the supreme power after Germany's unconditional surrender. The old-new German political parties had to face the state building under hard circumstances such as the lack of sovereignty. The postwar chaos could be overcome in four years, therefore two new states have been rebuilt on the territory of the 'Third Reich'. This study is restricted to present the birth of West Germany also known as Federal Republic of Germany from 1948 when the Western Powers officially announced the establishment of a federal state in the West German area.

Keywords: state establishment, Federal Republic of Germany, Allied Powers, Parliamentary Council, basic law

\section{Bevezetés}

1945 Németország történelmében ismét gyökeres fordulatot hozott. A totális vereség és a nemzetiszocialista rezsim bukása az országot minden korábbinál nehezebb helyzetbe hozta. A „III. Birodalom” területén négy különálló entitás (zóna) jött létre, amelyek gyakorlatilag csak rendkívül korlátozott mértékben léphettek egymással kapcsolatba a szövetséges katonai kormányzatok jóváhagyásával. A szövetséges hatalmak a feltétel nélküli kapitulációval átvették Németország felett a legfőbb hatalmat. A régi-új német politikai pártoknak a szuverenitás teljes hiánya mellett, szűk korlátok között kellett szembenézniük az államépítés feladatával.

A kezdeti kaotikus állapotokat négy év alatt sikerült annyira rendezni, hogy két új államalakulat jöhessen létre az egykori Német Birodalom területén. A tanulmány kizárólag NyugatNémetország, illetve a Német Szövetségi Köztársaság újjáépítésének bemutatására szorítkozik 1948-tól kezdődően, amikor is a nyugati hatalmak hivatalosan eldöntötték egy új szövetségi állam felállítását a nyugatnémet területeken.

\section{Az 1948 márciusi londoni konferencia}

Németország kettészakadásának előjelei már 1947-ben megmutatkoztak, amikor a négy győztes hatalom külügyminiszterei nem tudtak megegyezni a német kérdésben a novemberi és decemberi konferenciájukon. 1947. december 15-én a felek anélkül álltak fel a tárgyaló asztaltól, hogy kitűzték 
volna az újabb konferencia időpontját, így a külügyminiszterek egyeztető fóruma gyakorlatilag megszűnt létezni. Helyébe kisebb konferenciák és különféle testületek léptek, melyek azonban már nem a megszálló hatalmak közötti kompromisszumokra törekedtek, hanem az egyes zónákban végbemenő folyamatokkal foglalkoztak. A négyhatalmi külügyminiszteri konferencia után az amerikai és a brit külügyminiszter, Marshall és Bevin 1947. december 17-18-án tovább egyeztetett francia kollégájukkal, Bidault külügyminiszterrel a francia zóna és a Bizónia egyesítéséről, illetve a jövőbeni nyugatnémet területek sorsáról. Az amerikaiak és a britek azt az álláspontot képviselték, hogy 1948 nyaráig létre kell hozni a nyugati zónákban egy államapparátust és felállítani egy ideiglenes nyugatnémet kormányt, valutareformot kell végrehajtani, Nyugat-Németország gazdaságát a Marshall-terv segítségével talpra kell állítani, valamint be kell vonni a nyugat-európai gazdasági és katonai integrációba. ${ }^{1}$

A nyugatnémet országrész egyesítését a francia ellenállás lassította. Abban egyetértés mutatkozott az amerikai és a brit kormánnyal, hogy a nyugat-európai integráció előmozdításával kell megfékezni a kommunista expanziót, azonban a franciák németektől való félelme legalább akkora volt, mint a szovjetek terjeszkedésétől. A francia kormány Németország-politikáját négy pont határozta meg: ${ }^{2}$ a franciák Saar-vidékre való igényének elismertetése; a Ruhr-vidék határozatlan időre szóló nemzetköziesítése csekély német részvétel mellett, és annak szövetséges megszállása; a nyugatnémet tartományok laza konglomerátumként való egyesítése a 19. század első felében ismert Német Szövetség (Deutscher Bund) mintájára; az újonnan létrejövő nyugatnémet állam tartós lefegyverzése.

A Saar-vidékkel és a demilitarizációval kapcsolatos francia igények támogatására még hajlott az amerikai és a brit kormányzat, azonban a másik két pont ellenkezett az általuk elképzelt nyugateurópai újjáépítési programmal. Az 1948. februári hathatalmi konferencián (USA, Nagy-Britannia, Franciaország, Benelux-államok) sem látszódtak enyhülni ezek az ellentétek a nyugati szövetségesek között. A merev francia ellenállás több tényezőre volt visszavezethető. A háború utáni gazdasági helyzet, a katonai gyengeség, a gyarmati birodalom fellazulása és a németektôl való félelem nem tették lehetôvé, hogy a francia külpolitika ténylegesen érdekelt legyen egy egységes NyugatNémetország létrejöttében. A várt francia külpolitikai enyhülést végül a nemzetközi események hozták meg. A kommunista hatalomátvétel Csehszlovákiában, és Sztálin nyomásgyakorlása Titora, hogy Jugoszlávia lépjen be a szovjet szatellitállamok sorába, meggyőzték a francia politikai vezetést, hogy a kommunizmus elleni harcban egy stabil Nyugat-Németország erôs szövetségesnek bizonyulhat. Az enyhülés első jeleként a francia kormányzat hozzájárult, hogy a német képviselet részt vegyen az OEEC elődjének, az Európai Gazdasági Együttmúködés Tanácsának (Council of European Economic Cooperation) nyitó ülésén. Az amerikai kormányzat döntése, miszerint az Egyesült Államok megerôsíti az Európában állomásozó csapatainak jelenlétét, egész Nyugat-Európában, így Franciaországban is pozitív fogadtatásra talált. A francia kormány így egy erôs szövetségest talált magának nemcsak a Szovjetunió ellen, de egy esetleges jövőbeni német katonai agresszió esetén is. Marshall külügyminiszter javaslata a Ruhr-vidék egy nyugat-európai integráció keretében

\footnotetext{
${ }^{1}$ GÖRTEMAKER, Geschichte der Bundesrepublik Deutschland 44-45.

${ }^{2}$ GÖRTEMAKER, Geschichte der Bundesrepublik Deutschland 46.; KRAUS, Ministerien für das ganze Deutschland? 48.
} 
megvalósuló nemzetközi ellenőrzés alá vonására részben egyezett a francia kormány külpolitikai követeléseivel, ami szintén kedvező hatást gyakorolt a franciák Németország-politikájára. ${ }^{3}$

A konferencia végén sikerült megegyezni a katonai garanciákról, a nyugat-európai integrációról és a nyugatnémet államalapításról. A francia külügyminiszter elégedetten távozhatott a tárgyaló asztaltól, mert egyrészt a Saar-területre vonatkozó francia igényeket érvényesíteni tudta, másrészt sikerült lassítani a nyugatnémet államépítés folyamatát. Az amerikai és a brit nyugatnémet újjáépítésről szóló tervek egy azonnali ideiglenes nyugatnémet kormány felállításáról, és az azt követő alkotmány kidolgozásáról szóltak annak érdekében, hogy legkésőbb 1948 őszére felálljon egy elismert, legitim nyugatnémet kormány. A francia követeléseknek megfelelően ezt a folyamatot végül fordítva valósították meg, ezzel is hátráltatva az újjáépítést. ${ }^{4}$

Az 1948. február és június között tartott (1948. február 23. - március 6., majd április 20. június 1.) londoni hathatalmi konferencia eredményeként 1948. június 2-án kiadták a Londoni Ajánlásokat, amelyeket továbbítottak a hat hatalom kormányai felé. Miután az egyes kormányok jóváhagyták azokat, június 7-én egy második kibővített közleményt is kiadtak a konferencián született döntésekről. Az Ajánlások tartalmazták a nyugatnémet államalapításra való felhatalmazást, amelyet a három nyugati hatalom katonai kormányzói adtak át két másik dokumentummal együtt a 11 nyugatnémet tartomány miniszterelnökeinek az 1948. július 1 -jei találkozójukon. ${ }^{5}$ A június 7-én kihirdetett közlemény magában foglalta, hogy a nyugati zónákhoz tartozó német területeket egy olyan alkotmány elfogadásával kell egyesíteni, mely garantálja a föderatív állami berendezkedést, megvédi a tartományok hatásköreit, biztosítja a tartományok feletti központi hatalom múködését, és garantálja az egyéni jogokat. ${ }^{6} \mathrm{~A}$ hathatalmi konferencia az alkotmánytervezet kidolgozását az erre a célra létrehozandó alkotmányozó gyưlésre (verfassunggebende Versammlung) bízta, és közleményében kinyilvánította, hogy az alkotmány elfogadását népszavazásra fogják bocsátani az egyes tartományokban. ${ }^{7}$

A három nyugati katonai kormányzó 1948. július 1-jén a nyugati tartományok miniszterelnökeinek Frankfurtban átnyújtott dokumentumai a Frankfurti Dokumentumok néven vonultak be a történelembe. A Frankfurti Dokumentumok a következő ajánlásokat tartalmazták: ${ }^{8}$ Az I. Dokumentum felszólította a 11 nyugatnémet tartomány miniszterelnökét, hogy hívjanak össze egy alkotmányozó gyűlést 1948. szeptember 1-ig, melynek feladata lesz egy föderális alapokon nyugvó, demokratikus és az egyén jogait garantáló alkotmány kidolgozása valamennyi nyugatnémet tartomány számára. A II. Dokumentum azzal bízta meg a miniszterelnököket, hogy vizsgálják meg, milyen lehetőségek vannak a nyugatnémet tartományi határok újraszervezésére. A III. Dokumentum a később elfogadásra kerülő, a jövőbeni nyugatnémet kormányzat és a megszálló hatalmak közötti kapcsolattartást rendező Megszállási Statútum alapjait fektette le.

\footnotetext{
${ }^{3}$ GÖRTEMAKER, Geschichte der Bundesrepublik Deutschland 46-48.

${ }^{4}$ GÖRTEMAKER, Geschichte der Bundesrepublik Deutschland 49.

${ }^{5}$ GÖRTEMAKER, Geschichte der Bundesrepublik Deutschland 49.

${ }^{6}$ A nyugatnémet állam megalakításáról született döntés után 1948. március 20-án a Szovjetunió kivonult a Szövetséges Ellenőrző Bizottságból, júniusban a szovjet főparancsnok pedig elhagyta a berlini Szövetséges Főparancsnokságot, mellyel a szövetségesek közötti egyeztetések csak a legfontosabb ügyek megtárgyalásához szükséges mértékủre korlátozódtak, és az egyes megszállási zónákban szabad kezet kaptak a megszálló hatalmak.

${ }^{7}$ LAUFER - MÜNCH, Das föderative System der Bundesrepublik Deutschland 73.

${ }^{8}$ LEHMANN, Deutschland-Chronik 1945 bis 2000. 29. vö. SCHWACKE - STOLZ, Staatsrecht mit Allgemeiner Staatslehre und Verfassungsgeschichte 64.
} 
A miniszterelnökök a Frankfurti Dokumentumokkal megkapták a felhatalmazást, hogy létrehozzanak egy új szövetségi államot, ugyanakkor fennállt a veszélye, hogy egy nyugatnémet állam létrejöttével Németország felosztása konzerválódna. Az 1948. július 8-10. között tartott koblenzi konferencián a miniszterelnökök több ponton is kifogásolták az átnyújtott Dokumentumokat, és egyfajta politikai kompromisszumként javaslatot tettek arra, hogy az alkotmányozó gyúlés helyett egy Parlamenti Tanács (Parlamentarischer Rat) üljön össze, mely az alkotmány (Verfassung) helyett az laptörvényt (Grundgeseta) dolgozza ki. Emellett javasolták, hogy az Alaptörvényt ne népszavazás útján, hanem a tartományi parlamentek fogadják el annak érdekében, hogy kerüljék az Alaptörvény alkotmányként való aposztrofálását. A rendelkezésre álló idő rövidsége miatt a miniszterelnökök továbbá szorgalmazták, hogy a tartományi határok rendezését napolják el. ${ }^{9}$ A III. Dokumentummal kapcsolatban megjegyezték, hogy a külkereskedelmi korlátozásokat fel kellene oldani, és a korlátozások helyett a nyugatnémet külkereskedelmet szövetséges felügyelet alá kellene helyezni. A Koblenzi Határozatok (Koblenžer Beschlüsse) elsősorban Clay amerikai kormányzó nemtetszését váltották ki, aki úgy érezte, hogy a nyugatnémet miniszterelnökök nem ismerték el a szovjetekkel szembeni, Berlinért folytatott fáradozásait és a francia katonai kormányzó meggyőzésére tett erőfeszítéseit, hogy a francia zóna csatlakozásával létrejöjjön az új nyugatnémet állam. Többszöri egyeztetés után nehezen ugyan, de végül megszületett a megoldás, amikor a három nyugati katonai kormányzó és a 11 nyugatnémet tartomány miniszterelnöke 1948. július 26-án, a felforrósodott politikai légkörben az Alkotmányozó Konvent megalakulása előtt utoljára találkozott. A kormányzók beleegyezésüket adták, hogy az alkotmány helyett az alaptörvény elnevezés legyen használatos a nyugatnémet állam alkotmányos alapdokumentumára. Az alaptörvény népszavazásra bocsátását a miniszterelnökök javaslatára elvetették, az alaptörvény kidolgozásáért felelős grémium az Alkotmányozó Nemzetgyülés (Verfassunggebende Nationalversammlung) helyett a Parlamenti Tanács (Parlamentarischer Rat) elnevezést kapta, és a tartományi határok rendezésének ügyét későbbre halasztották. ${ }^{10}$

\section{A Herrenchiemsee-i Alkotmányozó Konvent}

A miniszterelnökök az I. Dokumentum által biztosított mandátum alapján az 1948. július 25-én kiadott határozatukkal felállítottak egy szakértői bizottságot, melynek feladata volt előkészíteni a később összeülő Parlamenti Tanács munkáját. Tagjai a tartományi kormányok által kinevezett szakértők voltak, akik a Chiemsee tavi Herreninselen (Herren-sziget - Urak Szigete) található Herrenchiemsee kastélyban 1948. augusztus 10-23. között tanácskoztak, és megalkották a föderális alapokon nyugvó új nyugatnémet állam alkotmánytervezetét (alaptörvény-tervezetét). ${ }^{11}$

A bajor delegáció a „Bajor vezérgondolatok az. Alaptörvény kidolgozásáboz” címet viselő előzetes dokumentummal készült a konventre, melyben Bajorország azon kívánságát szerette volna érvényre juttatni, hogy a szövetség a tartományok produktuma, ́́gy csak korlátozott hatáskörökkel bír. Az Alkotmányozó Konventben a 11 tartomány delegáltja mellett a nyugat-berlini Városi Küldöttgyűlés (Stadtverordnetenversammlung) elnöke, Otto Subr is részt vett vendégként. A delegáltak

\footnotetext{
${ }^{9}$ LAUFER - MÜNCH, Das föderative System der Bundesrepublik Deutschland 74.

${ }^{10}$ FELDKAMP, Der Parlamentarische Rat 1948-1949 23 -28.

${ }^{11}$ MußGnug, Zustandekommen des Grundgesetzes und Entstehen der Bundesrepublik Deutschland 232-233.
} 
különböző szakterületek képviselői voltak, akik eltérő politikai beállítottsággal és alkotmányjogi felfogással rendelkeztek. Voltak köztük tartományi kormánypolitikusok és hivatalnokok, jogprofesszorok és egykori diplomaták is. Hivatalosan valamennyien pártpolitikailag függetlenek voltak. A Konventtel szembeni elvárások magasak voltak, még ha nem is várták el a résztvevőktől, hogy az alkotmány végleges szövegét alkossák meg. Mindazonáltal mindenki bízott abban, hogy a Konvent által kidolgozott alkotmányszöveg a jövőben összeülő Parlamenti Tanács munkájának vezérfonalául fog szolgálni majd. A Konvent munkáját nehezítette, hogy az ülések nem zárt ajtók mögött, a nyilvánosságot kizárva zajlottak. A plenáris vitát követően a Konvent a kijelölt feladatoknak megfelelően három bizottságra oszlott. A bizottságok által kidolgozott javaslatokat további két plenáris ülésen vitatták meg. A 95 oldalnyi javaslat zárójelentését a szerkesztő bizottság készítette el, és bocsátotta a miniszterelnökök rendelkezésére, akik 1948. augusztus 31-én még egyszer utoljára összeültek, hogy a másnap megalakuló Parlamenti Tanács munkáját előkészítsék. ${ }^{12}$

Az alkotmánytervezet kidolgozása során a weimarizáció képe lebegett az alkotók szeme előtt, akik el akarták kerülni a korábbi alkotmány szerkezeti hiányosságait, amelyek az első német köztársaság bukását, és Hitler hatalomra kerülését lehetővé tették. A Konvent tagjai egyetértettek abban, hogy a jövőbeli államnak föderális szerkezetűnek kell lennie, melyben a törvényhozást, a közigazgatást, az igazságügyet és a pénzügyet a széleskörű decentralizáció jellemzi. További javaslat volt, hogy a szövetségi kormány - a weimari alkotmányos renddel ellentétben - egy határozatképes parlamentre támaszkodjon, azaz, hogy egy határozatképtelen parlament ne akadályozhassa meg egy új kormány alakulását, és ne buktathassa meg a hatalmon lévőt. A prezidenciális kormányformát és a népi kezdeményezés intézményét elvetették, a népszavazást egyedül alkotmánymódosítás esetén kívánták megtartani. Az alkotmánytervezet az államfőt semleges hatalomként definiálta a kormány mellett, aki a weimari köztársaság birodalmi elnökével ellentétben nem élhetett a szükségrendeleti kormányzás lehetőségével. A tervezet értelmében a szabadságjogokat és a demokratikus rendet korlátozó alkotmánymódosítások nem voltak megengedettek, az alapvető jogok alkotmányjogi védelmét pedig egy külön alapjogi katalógusnak kellett biztosítania, amelynek a törvényhozó, a végrehajtó és az igazságszolgáltató hatalom is alá van rendelve, és amelyet semmilyen körülmények között nem lehet hatályon kívül helyezni. ${ }^{13}$

A Konvent által kidolgozott tervezet a weimari alkotmány népi és központi hatalmi elemeit legyengítette, a parlament alsó házát és a kormány pozícióját megerősítette, az államfő hatalmi jogosítványait pedig gyakorlatilag kiüresítette. A bajor delegációnak a legyengített központi hatalmi garanciák sem voltak elengedők, és azt javasolták, hogy az új államalakulat középpontjába a tartományok kerüljenek, és belőlük alakuljon meg a szövetség, amelyhez bármely német tartomány csatlakozhat. A bajor javaslat szerint a szövetségnek a német egység helyreállitásáig a Német Tartományok Szövetsége (Bund Deutscher Länder) nevet kell viselnie, és az alkotmányt - ideiglenes mivoltát kihangsúlyozva - alaptörvényként kell elfogadni. Ennek a jogi felfogásnak az alapját a nemzetközi jogban ismert fogalom, a debelláció (debellatio) képezte. A debelláció akkor következik be, ha egy adott ország területét katonai erővel megszállják, és az ott található államhatalmat megsemmisítik. E felfogás szerint a feltétel nélküli kapituláció következtében tehát a német nép mint államalkotó tényező megszűnt létezni. Az újonnan alakuló állam nem a „Harmadik

12 GÖRTEMAKER, Geschichte der Bundesrepublik Deutschland 56-57.

${ }^{13}$ GÖRTEMAKER, Geschichte der Bundesrepublik Deutschland 57-58. 
Birodalom” jogutódja, legitimitása nem a „Harmadik Birodalomtól” származik, és szuverenitása jogilag nem köthető a múltbéli államalakulatokhoz. Az új, cselekvőképes német állam apparátusát nem elég csak újjászervezni, az alkotmányozási folyamat révén egy új államot kell létrehozni, a már alkotmányosan megalakult tartományokból. ${ }^{14}$

A Konvent delegáltjainak többsége nem értett egyet ezzel a felfogással, az alkotmányozó hatalmat ugyanis nem a tartományoktól, hanem a néptől származtatta. Nézetük szerint Németország megosztottsága ellenére a német népnek jogában állt politikai létezését tartalmilag és formailag meghatározni. A német nép ezen joga a feltétel nélküli kapitulációval és a fôhatalom szövetségesek általi átvételével nem szűnt meg létezni, csupán felfüggesztették azt a megszálló hatalmak. A többség tehát egy átmeneti nyugatnémet állam létrehozása mellett szállt síkra, amelynek legitimitása és szuverenitása közvetlenül a néptől ered, és hangsúlyozták, hogy a jövőben újraegyesített Németország magállamát (Kernstaał) az ideiglenes nyugatnémet állam fogja alkotni. Abban egyetértés mutatkozott a delegáltak többsége és a bajor delegáció között, hogy az ideiglenes alaptörvénynek lehetôvé kell tennie, hogy Németország többi része szabadon csatlakozhasson később a szövetséghez. ${ }^{15}$

A Konvent nem csupán a jövőbeli alkotmány keretét dolgozta ki, hanem a Grundgesetz. majdhogynem teljes egészét. A tervezetet a politikusok többsége negatívan fogadta a túlzott föderális jellege miatt. Konrad Adenauer, későbbi nyugatnémet kancellár, és Carlo Schmid, akit az alkotmányozó gyúlés során nyújtott kiemelkedő munkája miatt szokás a Grundgesetz. egyik atyjának is nevezni, az alkotmánytervezet kötetlen mivoltát hangsúlyozták, melyet a Parlamenti Tanács megalakulása után akár teljes egészében is elvethet. A Herrenchiemsee-i alkotmánytervezet mellett a tartományi miniszterelnököknek további két dokumentumot is benyújtottak: az egyik a CDU és a CSU által közösen kidolgozott ellwangen-düsseldorfi tervezet, a másik az észak-rajna-vesztfáliai belügyminiszter és miniszterelnök-helyettes, az SPD elnökségéhez tartozó Walter Menzeltól származó tervezet volt. A tervezeteket 1948. augusztus 31 -én a Niederwaldban összehívott harmadik trizonális konferencián vizsgálták meg a miniszterelnökök. A Herrenchiemsee-i ajánlások jelentőségét kezdetben alábecsülték, a Parlamenti Tanács azonban azokat használta tárgyalási alapként későbbi tanácskozó munkája során. ${ }^{16}$

\section{A Parlamenti Tanács}

A Parlamenti Tanács tagjai választásának módjáról a tartományi parlamentek szabadon dönthettek, a szövetségesek nem avatkoztak bele. 1948 augusztusában valamennyi tartományi parlament elfogadta a Parlamenti Tanács képviselőinek választásáról szóló törvényt, és ennek megfelelően megválasztották a képviselőket. A három nyugatnémet zóna összesen 65 képviselôt delegált. A Parlamenti Tanács a következő bizottságokra tagolódott: ${ }^{17}$ Alapvető Ügyek Bizottsága (Ausschußfür Grundsatıfragen); a Szövetség Megszervezéséért, az Alkotmánybíróságért és az Igazságszolgáltatásért Felelős Bizottság vagy más néven Kombinált Bizottság (Ausschuß für Organisation des Bundes sowie

\footnotetext{
${ }^{14}$ GÖRTEMAKER, Geschichte der Bundesrepublik Deutschland 58.

15 GÖRTEMAKER, Geschichte der Bundesrepublik Deutschland 58-59.

16 GÖRTEMAKER, Geschichte der Bundesrepublik Deutschland 59.

${ }^{17}$ EsCHenburg, Das Problem der Neugliederung der deutschen Bundesrepublik 244.
} 
Verfassungsgerichtshof und Rechtspflege, röviden Kombinierter Ausschuß); a Hatáskörök Rendezéséért Felelős Bizottság (Ausschuß für Zuständigkeitsabgrenzung); a Pénzügyi Bizottság (Ausschuß für Finan̊fragen); a Választójogi Ügyek Bizottsága (Ausschuß für Wablrechtsfragen) és a Megszállási Statútum Bizottsága (Ausschuß für das Besatzungsstatut).

A Parlamenti Tanács nyitóünnepségére 1948. szeptember 1-jén, a bonni Koenig Múzeum világítóudvarában került sor. Az ünnepélyes nyitányt az alakuló ülés követte a Pedagógiai Akadémia épületében, ahol a tantermek az egyes frakciók rendelkezésére álltak. A Bonnban összeült Parlamenti Tanács munkájának vezérfonalaként a kidolgozott alkotmánytervezet szolgált. Az asszisztált alkotmányozás során a szövetséges hatalmak ajánlásokkal avatkoztak be, melyek többnyire a föderális struktúra erősítését szolgálták, illetve Berlin különleges státuszát szavatolták. ${ }^{18}$

A Parlamenti Tanács ülésein a nyugat-berlini képviselők is jelen voltak kizárólag tanácskozási joggal, szavazati jog nélkül. Az ülések során kialakult viták nagy része az újonnan létrejövő föderatív modellt érintették. A demokrácia alapelveiről egyetértés mutatkozott, amely arra volt visszavezethető, hogy a képviselők tudatában még erősen jelen volt a weimari köztársaság személyesen átélt bukása. Az államfő jogállását tekintve a CDU/CSU koalíció és az SPD között nem mutatkozott éles ellentét. Előbbi javasolta, hogy a szövetségi elnöknek csak korlátozott jogkörei legyenek, míg az utóbbi a korábbi birodalmi elnöki, Hindenburg hatalommal való visszaélését szem előtt tartva, a szövetségi elnöki pozíció megszüntetésére tett javaslatot, egészen pontosan a Bundestag elnökére, vagy a kancellárból és a parlament két kamarájának elnökéből álló kollektív testületre ruházta volna a feladatait. Kompromisszumként a szövetségi elnöki hivatal megmaradt, de a képviselők egy erősen korlátozott jogosítványokkal bíró államfői pozícióban állapodtak meg. Az államfö elveszítette a kormányalakításra vonatkozó jogait, a kancellár megválasztása és megbuktatása egyedül a Bundestag hatáskörébe került. A kancellár szerepe szintén erősödött azáltal, hogy kizárólag ő döntött a kormány összetételéről. A szövetségi elnök legitimációját tovább gyengítve döntés született arról, hogy nem közvetlen választás útján fogják választani, hanem a Bundestag meghatározott számú képviselőiből és a tartományi parlamentek megegyező számú képviselőjéből álló Szövetségi Gyűlés (Bundesversammlung) választja majd közvetetten. ${ }^{19}$

Az alkotmányozó tanács csak egy ideiglenes alaptörvényt kívánt kidolgozni, ${ }^{20}$ melyet átmeneti jogforrásnak szántak, ugyanis az alkotmány elfogadását a német egység újbóli létrejöttéhez kötötték. A neves jogtudós, Carlo Schmid felhívta a figyelmet arra, hogy a Grundgesetz esetében nem csupán egy mindenki által ideiglenesnek szánt, degradált alkotmányjogi dokumentumról van szó, hanem jóval többről, egy tartós alkotmányról, aminek egész Németország számára modellt kell állítania. E felfogása miatt méltán nevezik ôt a német alkotmányos rend atyjának. ${ }^{21}$

Az új állami berendezkedésről sok vita folyt a Parlamenti Tanács ülésein. A képviselők között egyetértés mutatkozott abban, hogy az egyébként a szövetséges hatalmak által is megkövetelt szövetségi állami modellt kell megvalósítani, a tartományok jogállásának és hatáskörének kérdése ugyanakkor vitapontot jelentett. A viták aggodalmakat szültek a szövetséges kormányok körében, hogy vajon megszülethet-e a mindkét politikai irányzat számára megfelelő kompromisszum.

\footnotetext{
${ }^{18}$ Eschenburg, Das Problem der Neugliederung der deutschen Bundesrepublik 244.

${ }^{19}$ GÖRTEMAKER, Geschichte der Bundesrepublik Deutschland 66-67.

${ }^{20}$ BAUER-KIRSCH, Zur Legitimation des Bonner Grundgesetzes 173.

${ }^{21}$ GÖRTEMAKER, Geschichte der Bundesrepublik Deutschland 67.
} 
Időközben a három nyugati külügyminiszter 1949. április 5-8. között tartott washingtoni konferenciáján aláírta a Megszállási Statútumot, amelyet április 10-én nyújtottak át a Parlamenti Tanácsnak. A Statútumot a képviselők is jól fogadták, mert az összhangban állt az Alaptörvénnyel, így nem kellett már jelentős módosításokat végrehajtani rajta. A Parlamenti Tanács a megszülető Német Szövetségi Köztársaság Alaptörvényének harmadik olvasatát pontosan négy évvel a feltétel nélküli kapituláció után, 1949. május 8-án fogadta el. ${ }^{22}$

A Grundgesetž elfogadása után, május 10-én a Parlamenti Tanács Bonnt tette meg a szövetségi kormányszervek ideiglenes székhelyévé. A döntést többhónapos vita és lobbi előzte meg. Bonn mellett Frankfurt pályázott eséllyel a szövetség fóvárosa címre. Ez utóbbit a Parlamenti Tanács szociáldemokrata képviselői szorgalmazták, Bonn mellett pedig Adenauer és az észak-rajnavesztfáliai állami kancellária vezetője, Hermann $W$ andersleb kardoskodott. Adenauer azzal érvelt, hogy a jövő Németországának magját képező Szövetségi Köztársaság fővárosát a Rajna-vidéken kell kijelölni az európai tradíciók jegyében, ugyanis a Rajna-vidék és a nyugati szomszédos államok közötti kapcsolatok sokkal szorosabbak, mint a Frankfurt és a nyugati szomszédos államok közöttiek. Robert Murphy amerikai diplomatát azzal igyekezett meggyőzni, hogy Bonn fővárossá tételével elejét lehetne venni a Rajna bal partjára még mindig fennálló francia területi követeléseknek, ${ }^{23}$ valamint felhívta a figyelmet arra, hogy egy szovjet támadás esetén Frankfurt kiszolgáltatottabb helyzetbe kerülne, mint Bonn. A szociáldemokrata Carlo Schmidet pedig azzal próbálta megnyerni ügyének, hogy rámutatott, a Frankfurtban működő amerikai katonai kormányzat és az egykor szintén ott ülésező Gazdasági Tanács utódszervei csak akadályoznák a szövetségi kormány és törvényhozás munkáját, ezzel szemben Bonn ideális helyszín lenne mindkettőnek. Azt is kiemelte, hogy Bonnban az esetleges tüntetések szerveződése sem jelentene problémát a kis lakosságszám miatt. A brit katonai kormányzat biztosította Adenauert arról, hogy amennyiben Bonn fog otthont adni a Szövetségi Köztársaság kormányzati szerveinek, úgy demilitarizált övezetté fogják nyilvánítani. Bonnban belga csapatok állomásoztak, amelyek a kis katonai kormányzati apparátus miatt könnyen kivonhatók voltak a területről. Ezt az ígéretet Adenauer szintén érvként használta fel, és hangsúlyozta, hogy ez Frankfurtban kivitelezhetetlen lenne, ugyanis a város adott helyet az amerikai katonai kormányzat szerveinek, amelyeket elképzelhetetlen lett volna leépíteni. Wandersleb ezentúl az új kormányzati székhely kijelölésének az anyagi vonzatát kiemelendő javasolta, hogy Bonn legyen az új főváros, mivel egy másik város választása esetén az új kormányszékhely kialakításának költségei jelentősen megugranának. ${ }^{24}$

Adenauer akkurátusan rendszerbe szedett érveinek ellenére a választás csaknem a Majnaparti városra esett, ugyanis a Parlamenti Tanács szociáldemokrata képviselói továbbra is ragaszkodtak ahhoz, hogy Frankfurt legyen az új fơváros. Adenauernek kedvezett, hogy a nyugatberlini föpolgármester, Ernst Reuter és az általa vezetett szociáldemokrata képviselők is Bonnt kívánták megtenni a jövôbeli Szövetségi Köztársaság fővárosának, mivel a gazdag történelemmel rendelkező Frankfurttal ellentétben Bonn kevésbé bírt jelentőséggel. Ezt szem előtt tartva azzal érveltek, hogy a német újraegyesítést követően könnyebben vissza lehetne telepíteni Berlinbe a kormányzati szerveket. A kereszténydemokrata párt érdekeit nem gátolva és a saját tartományuk

\footnotetext{
22 GÖRTEMAKER, Geschichte der Bundesrepublik Deutschland 67-70.

${ }^{23}$ HÜSER, Die Saar-Politik und die deutsch-französische Geschichte an der Grenze 49.

${ }^{24}$ GÖRTEMAKER, Geschichte der Bundesrepublik Deutschland 71-73.
} 
érdekein felülemelkedve Hessen tartomány mindkét képviselője Bonnra adta le szavazatát 1949. május 10-én. A döntés végérvényesen a Bundestag november 3-i ülésén született meg, amikor ismételten megvitatták, hogy Bonn vagy Frankfurt legyen-e a főváros. A döntés ezúttal is az elóbbire esett. ${ }^{25}$

\section{Az Alaptörvény elfogadása}

Miután a Parlamenti Tanács 1949. május 8-án elfogadta az Alaptörvény harmadik olvasatát, a végső döntés a katonai kormányzók kezébe került, hogy jóváhagyják-e azt. A döntést sürgette, hogy közeledett az 1949. május 23. és június 20. között megrendezésre kerülő négyhatalmi külügyminiszteri konferencia Párizsban. A nyugati szövetségesek tartottak attól, hogy amennyiben nem fogadják el az Alaptörvény tervezetét a konferencia kezdete előtt, úgy a Szövetségi Köztársaság megalakulása elhúzódhat. A folyamat meggyorsításának érdekében május 12-én meghívták a Parlamenti Tanács és a miniszterelnökök delegációját Frankfurtba, hogy bejelentsék az Alaptörvény elfogadását. Ez a nap szimbolikus jelentőséggel bírt. Május 13. péntekre esett, ́́gy el akarták kerülni a baljós dátumot, mindemellett május 12. volt Lucius Clay tábornok megbízatásának utolsó napja, aki a Grundgesetz jóváhagyásával és a berlini blokád feloldásával ünnepélyesen kívánt leköszönni. A hivatalos jóváhagyó dokumentumot a találkozó elnökeként Robertson brit katonai kormányzó adta át a Parlamenti Tanács elnökének és a későbbi kancellárnak, Konrad Adenauernek. ${ }^{26}$

Az engedélylevélben a nyugati hatalmak elégedettségüket fejezték az Alaptörvénnyel kapcsolatban, mely a jogrendjével az újonnan létrejövő szövetségi köztársaság szilárd alapját fogja képezni, mindazonáltal fenntartották maguknak a jogot, hogy az Alaptörvény 91. cikk (2) bekezdésében foglalt rendőri erőszak gyakorlását a megszálló hatóságok előzetes engedélyéhez kössék. Nyugat-Berlin vonatkozásában kikötötték, hogy nem rendelkezhet szavazati joggal sem a Bundestagban, sem a Bundesratban, azonban az üléseiken képviselőik részt vehettek megfigyelőként. A 84. és a 87. cikkek tekintetében, melyek széles hatásköröket biztosítottak a szövetségnek a közigazgatás területén, biztosítékot vállaltak arra, hogy megakadályozzák a túlzott hatalomkoncentráció kialakulását. A tartományi alkotmányok és az Alaptörvény ütközése esetén pedig megkövetelték, hogy magasabb szintű jogszabályként az Alaptörvény rendelkezéseit kell figyelembe venni. ${ }^{27}$

A Parlamenti Tanács munkájának befejeztével az a mindaddig nyitott kérdés is eldőlt, hogy az Alaptörvényt nem népszavazás útján, hanem a tartományi parlamentek fogadják el a közvetett demokrácia elvének megfelelően. A katonai kormányzók felhatalmazták a nyugatnémet tartományok miniszterelnökeit tömörítő testület, a Miniszterelnöki Értekezlet elnökét, Wilhelm Kaisent, hogy terjessze be az Alaptörvényt a tartományi parlamentek (Landtag) elé szavazásra. ${ }^{28}$

Az Alaptörvény elfogadásához a szövetséges hatalmak engedélyén túl szükség volt a nyugatnémet tartományok kétharmadának jóváhagyására is. A Parlamenti Tanács által elfogadott Alaptörvény tervezetének elfogadásáról 1949. május 18. és 21. között döntöttek a tartományi

\footnotetext{
${ }^{25}$ GÖRTEMAKER, Geschichte der Bundesrepublik Deutschland 73-74.

${ }^{26}$ FELDKAMP, Der Parlamentarische Rat 1948-1949 178-179.

${ }^{27}$ FELDKAMP, Der Parlamentarische Rat 1948-1949 179.

${ }^{28}$ FELDKAMP, Der Parlamentarische Rat 1948-1949 179-180.
} 
parlamentek. ${ }^{29}$ Bajorország kivételével valamennyi tartomány elfogadta a tervezetet. A bajor kormány kifogásolta, hogy a tartományok hatáskörei nem elég szélesek a föderalizmus megvalósításához, azonban az 1946-os bajor alkotmány 178. cikkének értelmében az a döntés született, hogy amennyiben a többi tartomány legalább kétharmada jóváhagyja a tervezetet, úgy Bajorország is hatályosnak ismeri el azt magára nézve. Ez a cikk ugyanis kimondta, hogy Bajorország csatlakozni fog egy jövőbeli német demokratikus szövetségi államhoz. ${ }^{30}$

A Parlamenti Tanács május 23-i utolsó ülésén hirdette ki, hogy valamennyi nyugatnémet tartomány elfogadta az Alaptörvényt. Az ülésen jelen voltak a 11 miniszterelnök és tartományi parlamenti elnök, a három nyugati hatalom képviselői, és egyéb vendégek is. Az Alaptörvényt a Parlamenti Tanács képviselői és a 11 miniszterelnök írták alá. Noha hatálya Berlinre nem terjedt ki, a nyugat-berlini Városi Képviselőgyúlés egyetértett annak alapelveivel és céljaival. Ezt kifejezendő a Városi Képviselőgyúlés jelenlévő öt képviselője és a nyugat-berlini főpolgármester, Ernst Reuter is csatlakozva a miniszterelnökökhöz, aláírták az Alaptörvény eredeti példányát, amely ezt követően 24:00 órakor lépett hatályba, létrehozva ezzel a Német Szövetségi Köztársaságot. ${ }^{31}$ Az asszisztált alkotmányozás jogszerűségét sok alkotmányjogász megkérdőjelezte, azonban a máig hatályos Alaptörvény bebizonyította, hogy sikerült megteremtenie egy demokratikus, szabad és föderatív működésű Németországot. ${ }^{32}$

\section{Viták a szövetségi állami modellről}

\section{1. Állami berendezkedés}

A háború utáni államépítés során az államforma kérdése körül a német politikai pártok sem képviseltek egységes álláspontot. Az újjáalakult pártok, a kommunista párt kivételével, egyetértettek abban, hogy Németországot egy föderatív államként kell újjáépíteni, azonban ennek módjáról már korántsem mutatkozott egyetértés. A Szabaddemokrata Párt (FDP - Freie Demokratische Partei) egy erős központi államhatalommal bíró birodalom ${ }^{33}$ felállítását támogatta, és javasolta, hogy a tartományok, a járások és a községek hatásköreit központilag határozzák meg. A Német Szociáldemokrata Párt (SPD - Sozialdemokratische Partei Deutschlands) a birodalmi jogot (Reichsrecht) kívánta a tartományi jog (Landesrecht) elé helyezni, és nem ismerte el a szövetségesek által meghúzott tartományi határokat, mondván azok nem vették figyelembe a történelmi, kulturális és gazdasági határokat. A tartományok létjogosultságát és a szövetséges hatalmak által elfogadott jogi aktusokat elfogadta. A Kereszténydemokrata Párt (CDU - Christlich Demokratische Union) követelte, hogy olyan önálló tartományok jöjjenek létre, melyek egy szabad szövetségi állam alkotóelemeiként múködnek. Ez a felfogás a tartományoknak adott nagyobb politikai mozgásteret. A legszélesebb tartományi

\footnotetext{
${ }^{29}$ FELDKAMP, Der Parlamentarische Rat 1948-1949 180.

30 VON BEYME, Das politische System der Bundesrepublik Deutschland 36.

31 FELDKAMP, Der Parlamentarische Rat 1948-1949 181-182.

$32 \mathrm{Az}$ a nézet, miszerint a német nép szabadon, az önrendelkezés alapján fogadta el az Alaptörvényt, nem állja meg a helyét, hiszen a szövetségesek rendszeresen ajánlásokkal avatkoztak be az alkotmányozás során, jóváhagyásuk nélkül nem fogadhattak el egyetlen rendelkezést sem, valamint a Grundgesetz kidolgozóit nem közvetlenül választották, és annak elfogadása nem népszavazás útján történt.

33 A korabeli döntéshozó körökben nem volt még egyértelmű, hogy az újonnan megalakuló államalakulat elnevezése birodalom vagy szövetség legyen. Erre utal a „birodalmi hatáskör” és a „,birodalmi jog” kifejezés, melyeket szinonimaként használtak szövetségi megfelelőjükkel.
} 
jogokat a bajor Keresztényszociális Unió (Csu Christlich-Soziale Union) követelte. A Bizónia központi szerveinek létrehozását kétkedve fogadta, ugyanis a jövőbeni központi kormányzat megtestesülését látta bennük, ami a centralizmus irányába való elmozdulást jelenti. A tartományi szuverenitást nemcsak a közigazgatási hatáskörök biztosításával akarta elérni, hanem valós államhatalmi jogosítványokat akart a tartományoknak, melyeket a központi hatóságok nem korlátozhatnak. Az államiság tartományi szintű kiépítésével gyakorlatilag tartományok helyett önálló államokat akartak létrehozni. A bajor párt ezzel a programmal kívánta elérni, hogy a német és az európai államközösség tagjaként létrejöjjön egy önálló bajor állam. ${ }^{34}$

A politikai pártok szövetségi állami berendezkedést érintő elképzeléseit egy skálán lehet a legjobban szemléltetni. A skála egyik végén az FDP állt egy erősen centralizált föderáció támogatásával, a másikon a bajor Csu egy erős tagállamokkal rendelkező decentralizált föderációs elképzeléssel, mely inkább egy államszövetségi modellhez hasonlított.

\subsection{Törvényhozó hatalom}

A Herrenchiemsee-ben összehívott Alkotmányozó Gyűlés (Verfassungskonvent) két hét alatt dolgozta ki alkotmánytervezetét, mely körül heves politikai viták bontakoztak ki a Parlamenti Tanácsban. Az egyik ilyen vitás pont a preambulummal kapcsolatban merült fel. A többség a „Bundesrepublik” (szövetségi állam), a kisebbség a „Bund deutscher Länder” (német tartományok szövetsége) megnevezést akarta belefoglalni az alkotmányba. ${ }^{35}$

A második kamara körül szintén politikai egyet nem értés mutatkozott. ${ }^{36}$ A Parlamenti Tanács tagjainak többsége egy „Bundesrat”-ot (Szövetségi Tanács), a kisebbség egy „Senat”-ot (Szenátus) akart felállítani a tartományok képviseletére, amelyet az amerikai modell ihletett. Előbbi a tartományi kormányok képviseletét hivatott ellátni, utóbbi a választott szenátorok testületeként funkcionál. A javaslat szerint a szenátorokat részben közvetlenül, részben közvetetten kell megválasztani, azaz másfél millió lakos állít egy szenátort, és a tartományok legalább egy, legfeljebb öt szenátort delegálnak a Szenátusba a népesség arányának megfelelően. ${ }^{37}$

A Bundesrat intézménye először a 19. században, az első, 1871-es bismarcki német birodalmi alkotmányban jelent meg. A második kamara gyökerei azonban jóval korábbra tehetők. A Szent Római Birodalom Örökös Birodalmi Tanácsa (Immerwährender Reichstag des Heiligen Römischen Reichs) 1663-ban jött létre, és a birodalmi rendek utasításhoz kötött követeinek gyúléseként funkcionált. Az 1866-ban megszűnt Német Szövetség (Deutscher Bund) legfőbb szerve, a Bundestag a német fejedelmek és a szabadvárosok szenátusa küldötteinek birodalmi gyúléseként múködött. Az 1871 es birodalmi alkotmánnyal létrehozott Bundesrat szövetségi szervként a központi állami szerv, a Reichstag ellensúlyát képezte, tagjai a tartományok kormányainak tagjai voltak. A törvényhozási folyamatban a Reichstag és a Bundesrat egyenjogú volt, mindkét szerv abszolút vétójoggal bírt a másik döntéseivel szemben. A Bundesrat a tartományi urak gyúlése és ezáltal alkotmányjogi értelemben

\footnotetext{
${ }^{34}$ LAUFER - MÜNCH, Das föderative System der Bundesrepublik Deutschland 75-77.

${ }^{35}$ LAUFER - MÜNCH, Das föderative System der Bundesrepublik Deutschland 82.

${ }^{36}$ FELDKAMP, Der Parlamentarische Rat und das Grundgesetz 32.

${ }^{37}$ LAUfER - MÜNCH, Das föderative System der Bundesrepublik Deutschland 82.
} 
véve a szuverenitás megtestesítője volt, a hatalmi egyensúly a gyakorlatban azonban a Reichstag és a központi állami szervek javára tolódott el. ${ }^{38}$

Az egykori Bundesrat hiányosságai ellenére hívei a háború utáni időszakban ragaszkodtak ismételt felállitásához, és akadtak, akik a szövetségivel egyenrangú szuverenitást követeltek a tartományok számára. Eszerint a koncepció szerint a Bundesrat egyenjogú lett volna a Bundestaggal, és a törvényjavaslatok csak a Bundestag és a Bundesrat egyező akarata esetén kerültek volna elfogadásra. A Bundesrat így szélsőséges esetben, a tartományi kormányok többségi akaratának megfelelően, a vétójogával élve megakadályozhatta volna valamennyi, a Bundestagtól érkező törvényjavaslat elfogadását. Ez a rendszer a klasszikus kétkamarás parlamenti rendszernek felelt volna meg. ${ }^{39}$

Az egyenjogú Bundesrat ötletének ${ }^{40}$ ellenzői kifogásolták a Bundesrat tagjainak demokratikus legitimációját, és tartottak attól, hogy a kötött mandátumú felsőház egy irányíthatatlan törvényhozó szervvé nőné ki magát. Alternatívaként egy szenátus felállítását javasolták, melyre a német alkotmánytörténetben korábban nem volt gyakorlati példa, jóllehet az 1848-49-es első Német Nemzetgyúlés (Deutsche Nationalversammlung) a frankfurti Szent Pál templomban tartott ülésein kidolgozott és elfogadott egy alkotmánytervezetet, melyet soha nem ültettek át végül a gyakorlatba. A javasolt szenátusi modell legitimációja nagyobb lett volna a Bundesrat modelljénél, ugyanis a szenátusi modellben a képviselők nem a tartományi kormányok, de még csak nem is a tartományi parlamentek tagjai, hanem vagy a tartományi parlamentek által vagy közvetlenül választott képviselők lettek volna. ${ }^{41}$

A szenátusi modell ellenzői viszont úgy vélték, hogy a tartományi parlamentek által választott szenátus felállítása esetén a szenátusban a tartományi parlamentekben uralkodó politikai viszonyok ismétlődtek volna meg, a képviselők közvetlen választása esetén pedig létrejött volna egy második Bundestag. Nézetük szerint a Bundestaggal megegyező politikai erejü szenátus csak erôsítette volna a Bundestag hatalmi pozícióját. Ehelyett a Bundesrat szükségességét hangsúlyozták, mely a szövetségi kormány és a Bundestag egyetlen ellensúlya lehet. ${ }^{42}$ A hosszas politikai diszkusszió után végül a Bundesrat felállítása mellett döntöttek.

További vitapont volt a Parlamenti Tanács (Parlamentarischer Rat) ülésein a föderációt illetően, hogy a tartományok ugyanannyi szavazattal bírjanak-e a Bundesratban, vagy a népességszámnak megfelelően kapjanak szavazatokat. Az SPD a népesség nagyságától függetlenül egyenlô szavazatot adott volna a tartományoknak az ún. aritmetikai elv alapján. A CDU/Csu ezzel szemben az ún. geometriai elvnek megfelelően a népességszám alapján akarta meghatározni a tartományok szavazatának számát. A kompromisszum az FDP javaslata alapján jött létre. E szerint a tartományok a népességszámnak és a geometriai elvnek megfelelően kapnak szavazatszámot a Bundesratban. ${ }^{43}$ Ennek következtében minden tartomány legalább három szavazatot kapott, ugyanakkor a nagyobb tartományok a lakosságszám arányában többletszavazathoz jutottak, így a

\footnotetext{
${ }^{38}$ LAUFER - MÜNCH, Das föderative System der Bundesrepublik Deutschland 82-83.

${ }^{39}$ LAUFER - MÜNCH, Das föderative System der Bundesrepublik Deutschland 82-83.

${ }^{40}$ FeldKAMP, Der Parlamentarische Rat und das Grundgesetz 32.

${ }^{41}$ LAUFER - MÜNCH, Das föderative System der Bundesrepublik Deutschland 82-83.

${ }^{42}$ LAUfER - MÜNCH, Das föderative System der Bundesrepublik Deutschland 84-85.

${ }^{43}$ LAUFER - MÜNCH, Das föderative System der Bundesrepublik Deutschland 86-87.
} 
kisebb tartományok nem lettek felülreprezentáltak, illetve a nagyobb tartományok sem tettek szert túlzott dominanciára.

\subsection{Megegyezés a szövetségi államformáról}

A Parlamenti Tanácsban a leghevesebb vitát a pénzügyi kérdések váltották ki, egészen pontosan, hogy a pénzügyekkel kapcsolatos jogalkotási, igazgatási hatáskörök és az adóbevételek hogyan oszoljanak meg a szövetség és a tartományok között. ${ }^{44}$ A szövetségi állami formáról szóló politikai vitákat felgyorsította a szövetséges hatalmak hathatós nyomása. Az így megszületett kompromisszum értelmében a pénzügyi igazgatás a szövetség és a tartományok között került felosztásra oly módon, hogy a pénzügyekkel kapcsolatos jogalkotás súlypontja a szövetségnél maradt, az adóügyi jogalkotásban pedig a Bundesrat a Bundestaggal azonos hatásköröket kapott. Az amerikai modellel ellentétben a német föderáció tartományai gyengébb hatásköröket kaptak, ezáltal az unitárius jelleg jobban kidomborodik. A törvényalkotási hatáskörök megoszlása tekintetében a szövetség erősödött meg. A szövetség és a tartományok együttmúködését erôsítette, hogy a szövetségi törvények végrehajtásánál a szövetség a tartományokra lett utalva, így az ezzel kapcsolatos igazgatási jog is a tartományokat illette. A „legyengített” föderatív modellben a tartományoknak ugyan kevesebb jogalkotási jogkör jutott, azonban a Bundesratban még mindig befolyással bírnak, és módosításokkal élhetnek egy törvényjavaslat elfogadása során. Ez a fajta fékező szerep a tartományi kormányokkal ellentétben a tartományi parlamenteknél hiányzik, melyek így a szövetségi jogalkotásban nem tudják érvényesíteni érdekeiket. A német föderalizmust ezért végrehajtó föderalizmusnak (Exekutivföderalismus) is szokták nevezni. ${ }^{45}$

\section{A genfi konferencia és következményei}

Az 1955. júliusi genfi konferencia volt az első olyan konferencia a Potsdami Konferencia óta, amelyen mind a négy győztes hatalom kormánya részt vett, beleértve a francia kormányt is, amely a Potsdami Konferencián még nem képviselte magát. Másik jelentősége abban rejlett, hogy ugyan csak megfigyelőként, de mindkét német állam képviselői részt vehettek rajta. A konferencián az általános leszerelési és biztonságpolitika szorosan összekapcsolódott a német újraegyesítés kérdésével. Ez utóbbi az első volt a napirendi pontok között. A nyugati hatalmak a német egyesítés után nem lettek volna hajlandók lemondani arról, hogy Németország kiváljon a nyugati gazdasági és katonai rendszerekből. A Szovjetunió ezzel szemben egy semleges Németországot képzelt el, amely a két tömb között helyezkedett volna el, nemzetközi kapcsolatait pedig egy az osztrák Államszerződéshez hasonló nemzetközi jogi dokumentum rendezte volna. Ez természetesen magával vonta volna, hogy Németország elhagyja a nyugati tömböt, amire nem volt reális esély. A megegyezést tovább hátráltatta, hogy a Szovjetunió miniszterelnöke, Bulganyin 1955. július 23-án bejelentette a konferencián, hogy a Német Demokratikus Köztársaság a Párizsi Szerződések fényében csatlakozni kíván a Varsói Szerződéshez, és a szovjet kormányfő nyíltan kiállt a „keét állam elmélete" mellett. A német újraegyesítés kérdésében tehát nem született előrelépés, azonban a négy

\footnotetext{
${ }^{44}$ FELDKAMP, Der Parlamentarische Rat und das Grundgesetz 32-33.

${ }^{45}$ LAUFER - MÜNCH, Das föderative System der Bundesrepublik Deutschland 87-88.
} 
hatalom képviselói megegyeztek abban, hogy a külügyminiszterek októberben ismét összeülnek Genfben. ${ }^{46}$

A genfi konferencia következményeként 1955. szeptember 8-14. között Moszkva vendégül látta az Adenauer vezette nyugatnémet delegációt. A találkozó eredményeként Adenauernek sikerült elérnie mintegy 10 ezer német hadifogoly szabadon engedését. A két fél megállapodott a diplomáciai kapcsolatok felvételében, azonban Adenauer egy külön levélben fejtette ki, hogy ez nem jelenti a meglévő területi viszonyok elismerését, melyet egy jövőbeli békeszerződésnek kell szabályoznia. A Bundestag szeptember 23-án hagyta jóvá a diplomáciai kapcsolatok felvételét. Adenauer ennek kapcsán kihirdette a Hallstein-doktrínát, mely a nyugatnémet külpolitika alapelvévé vált. A doktrína értelmében a nyugatnémet szövetségi kormány nem ismerte el a harmadik államok Kelet-Németországgal való diplomáciai kapcsolatfelvételét, és válaszul a saját kapcsolatait is felbontotta ezekkel az államokkal. Ez alól kivételt képezett a Szovjetunió és azok a keleti blokkhoz tartozó államok, amelyek még az NszK-val történő kapcsolatfelvételt megelőzően vették fel az NDK-val a diplomáciai kapcsolatokat. ${ }^{47}$

Az 1955 októberében megrendezett külügyminiszteri konferencia két ülésszakra oszlott. Az első 1955. október 27. - november 4. között, a második november 8-16. között zajlott. A konferencia, ahogyan az várható volt, nem hozott eredményt a német újraegyesítés kérdésében. A szovjet külügyminiszter, Molotov elutasította az össznémet szabad választások ötletét a nyugatnémet újrafelfegyverzésre hivatkozva, és a „két állam” javaslatot terjesztette a konferencia elé, ami már a júliusi genfi konferencián körvonalazódott. A nyugati külügyminiszterek javaslatában egy olyan zóna szerepelt, amelyben előírták volna a szovjet fegyverkezés korlátozását. Ehhez a zónához tartozott volna az egyesített Németország és egyes kelet-európai államok. A javaslat a biztonságpolitikával kapcsolatban előirányozta egy felügyeleti és egy figyelmeztető rendszer felállítását is. A javaslat értelmében minden államot megilletett volna az egyéni és a kollektív önvédelemhez való jog. Az új biztonságpolitikai rendszer felállítása kiegészült az Eden-tervvel. Ez utóbbi az össznémet szabad választásokról, az alkotmányozó nemzetgyűlés összehívásáról, az alkotmány kidolgozásáról, a központi kormány alakításáról és a német békeszerződésrôl szóló tárgyalások megkezdésérôl szólt. Molotov ezzel szemben kísérletet tett arra, hogy még a szabad választások megtartása előtt vegyék fel egyenjogú tagként az NDK-t és az NszK-t az új európai biztonságpolitikai rendszerbe. Emellett ismételten javaslatot tett egy össznémet tanács felállítására, és követelte az idegen katonai csapatok kivonását Németország területéről. A nyugati hatalmak nem meglepő módon elutasították a javaslatot arra hivatkozva, hogy a júliusi genfi konferencián a négy hatalom kormányfői abban állapodtak meg, hogy a szabad választások alapján megvalósuló újraegyesítés a biztonságpolitikai kérdésekkel azonos rangú, ́́gy ugyanolyan prioritással kezelendő. Ezzel párhuzamosan Molotov elutasította a nyugati külügyminiszterek javaslatát arra vonatkozóan, hogy állítsanak fel egy négyhatalmi bizottságot az 1956-os össznémet szabad választások előkészítésére. A nyugati hatalmak képviselői ezt szintén a júliusi genfi konferencián elfogadott direktívák megsértésének tekintették. ${ }^{48}$

\footnotetext{
${ }^{46}$ DÜWELL, Entstehung und Entwicklung der Bundesrepublik Deutschland 329-333.

${ }^{47}$ DüwELL, Entstehung und Entwicklung der Bundesrepublik Deutschland 334-335.

${ }^{48}$ DüWELL, Entstehung und Entwicklung der Bundesrepublik Deutschland 336.
} 
A genfi külügyminiszteri konferencia eredménytelenül zárult a tárgyaló felek között húzódó szakadéknak köszönhetően, ahogyan azt előre látni lehetett. A két tábor álláspontjai nem közeledtek egymáshoz, csupán megmerevedtek, és ugyanazok a problémák mutatkoztak meg, mint a kormányfők júliusi genfi találkozóján. Az 1955-ös év rámutatott arra, hogy a német egyesítés megoldhatatlan a nyugati és a keleti tábor közötti viszonyok normalizálódása és kiegyezése nélkül. A tárgyalásokat figyelembe véve megállapítható, hogy a nyugati hatalmaknak sem állt feltétlenül érdekében a német egyesítés, mivel nem voltak hajlandók belemenni a Nyugat-Németországban állomásozó csapatok kivonásába, illetve egy közös nyugatnémet-keletnémet intézmény felállításába, ezzel mintegy hosszú távon megpecsételve a kettéosztott Németország sorsát. Ez az álláspont alapvetően két tényezőre volt visszavezethető. Egyrészt tartottak attól, hogy csehszlovák mintára egy egyesített Németországban a kommunisták könnyú szerrel átvehetnék a hatalmat, és a középkelet és kelet-európai államokhoz hasonlóan szatellitállammá alakítanák. Másrészt sokak emlékezetében még ott éltek a németek háborús tettei, és gondolták úgy, hogy egy egységes német állam újra fenyegetést jelentene a kontinens békéjére nézve.

\section{8. Összegzés}

Németország kettészakadására már 1947 decemberében utaltak jelek, amikor a szövetséges külügyminiszterek konferenciájukon egyetértés hiányában álltak fel a tárgyalóasztaltól. Ezt követően csak alacsonyabb szintű egyeztetésekre került sor.

A német, illetve szúkebb értelemben a nyugatnémet egység létrejöttét nemcsak a nyugati és a keleti tábor közötti, de a nyugati szövetségesek közötti ellentétek is késleltették. A francia külpolitika központi eleme volt, hogy ellehetetlenítsék egy jövőbeni erős Németország létrejöttét. $\mathrm{Az}$ 1948. februári kommunista hatalomátvétel Csehszlovákiában, és az amerikaiak vállalása, miszerint megerôsítik az Európában állomásozó csapatok jelenlétét, a francia külpolitika enyhüléséhez vezettek. Az amerikai haderő a franciák számára nemcsak a szovjetek ellen jelentett biztonsági garanciát, de egyben a német gazdasági és katonai megerősödést is kontrolláltabb körülmények közé szorította.

Az 1948 februári és márciusi, valamint áprilisi és júniusi kétfordulós hathatalmi konferencián a nyugati szövetségesek megállapodtak Nyugat-Németország újjáépítésében. A Frankfurti Dokumentumokkal felhatalmazták a nyugatnémet tartományok miniszterelnökeit az államalapításra. A Dokumentumok előírták egy alkotmány elfogadását, amely egy szövetségi állam kereteit fogja megteremteni. A nyugatnémet miniszterelnökök tartottak attól, hogy a Dokumentumok elfogadása esetén a német megosztottság hosszú távon konzerválódna, ezért a Koblenzi Határozatokban javasolták felpuhításukat. A nyugatnémet javaslatok végül elérték eredményüket, mert a nyugati szövetségesek jóváhagyták, hogy alkotmányozó gyúlés helyett egy parlamenti tanács fogadjon el egy alkotmányjogi dokumentumot, amit alkotmány helyett alaptörvénynek fognak nevezni, és aminek elfogadását nem fogják népszavazásra bocsátani. Ezekkel kívánták a nyugatnémet alkotmány, illetve alaptörvény ideiglenességét kihangsúlyozni, meghagyva a keletnémet tartományok jövőbeni csatlakozásának elvi lehetőségét.

A miniszterelnökök az I. Dokumentumban foglaltak alapján felállítottak egy szakértői bizottságot (alkotmányozó konventet), amelynek feladata egy alaptörvény-tervezet 
(alkotmánytervezet) kidolgozása, és ezzel a majdan összeülő Parlamenti Tanács munkájának előkészítése volt. A tervezet két hét alatt készült el.

A kidolgozott alaptörvény-tervezet a népi elemeket legyengítette, a parlament alsó házának pozícióját megerôsítette. A konvent munkája során a bajor delegáció egy viszonylag gyenge központi hatalommal rendelkező szövetségi államot vagy inkább államszövetséget szeretett volna, amelynek a középpontjában a tartományok állnak a központi államhatalommal szemben. A konvent tagjainak többsége elvetette ezt a javaslatot, ugyanis nem a tartományoktól, hanem közvetlenül a néptől származtatták az alkotmányozó hatalmat, és kiemelték a nyugatnémet államalakulat ideiglenes mivoltát, amely a jövőben újraegyesített Németország magját fogja képezni.

A Parlamenti Tanács 1948. szeptember 1-jén kezdte meg munkáját Bonnban. Az ülések során számos pontban viták bontakoztak ki az egyes pártok között. Az államfő, azaz a szövetségi elnök intézményének felállításában (megtartásában) megegyezés született a CDU/Csu koalíció és az SPD között kialakult kompromisszumnak köszönhetően, azonban hatalmi jogosítványai gyakorlatilag szimbolikus jelentőségúek lettek.

Az állami berendezkedés körül szintén politikai viták generálódtak, ami aggodalmakat szült a szövetségesek között, hogy megszülethet-e a várva várt kompromisszum. A föderatív államszerkezetet illetően egyetértés mutatkozott ugyan, de a tartományi-szövetségi kompetenciák súlyának meghatározása már közel sem volt ennyire egyértelmú kérdéskör. A szövetségesek a Parlamenti Tanács munkája során több alkalommal is ajánlásokkal avatkoztak be. Az időközben elfogadott Megszállási Statútum, mely rendezte a születendő nyugatnémet állam kapcsolatait a nyugati szövetséges hatalmakkal, megnyugvással töltötte el a Parlamenti Tanács képviselőit, mivel az összeegyeztethető volt a készülő Alaptörvénnyel.

A Parlamenti Tanács 1949. május 8-án fogadta el az Alaptörvény végleges szövegét. Két nappal később, május 10-én többhónapos viták után döntés született a szövetségi fôvárosról is. A szociáldemokraták Frankfurtot szerették volna a szövetségi kormányzati szervek székhelyéül, ám végül az Adenauer vezette kereszténydemokraták javára dőlt el a kérdés. A főváros Bonn lett, ezzel is erősítve a nyugatnémet államiság ideiglenes jellegét. Hivatalosan csak november 3-án lett az, miután az újonnan megalakuló Bundestag is megszavazta azt.

Az Alaptörvényt a három nyugati szövetséges katonai kormányzója május 12-én hagyta jóvá engedélylevelével, amellyel a szövetségesek bizonyos jogokat fenntartottak maguknak. Az Alaptörvény mihamarabbi elfogadása sürgető volt a nyugati hatalmak, és egyben a nyugatnémet vezetés számára is, mivel közeledett a május 23-án kezdődő négyhatalmi konferencia, és félő volt, hogy az azon történő események lassíthatják vagy eltolhatják a nyugatnémet államalapítás folyamatát. A tartományok parlamentjei május 18. és 21. között fogadták el az Alaptörvényt Bajorország kivételével, a bajorok azonban meghajlottak a többség akarata előtt, és magukra nézve is hatályosnak ismerték el azt. Az Alaptörvény 1949. május 23-án éjfélkor lépett hatályba.

Az 1949-es év a két német államalapítással hosszú időre megpecsételte Németország sorsát. A hidegháború elmélyülése után az 1955-ben megrendezett genfi konferenciák bizakodásra adtak okot, ahol a legmagasabb szinten kezdődtek meg az egyeztetések a német újraegyesítésről. Az álláspontok azonban azok ellenére sem közeledtek. A Szovjetunió alapvetően arra törekedett, hogy az NszK-t kiszakítsa a nyugati tömbből, és egy Ausztriához hasonló semleges államként a semleges közép-európai térségbe illessze, ami elképzelhetetlen és irreális követelés volt. A nyugati hatalmak 
össznémet választásokat szorgalmaztak az egyesítés érdekében, amitől pedig a szovjet fél zárkózott el mereven. Ezeket figyelembe véve kijelenthető, hogy igazán egyik oldalnak sem állt érdekében az egységes Németország létrejötte, mert egyik oldal sem volt hajlandó lemondani követelései, illetve jogai egy részéről. A Szovjetunió azonban a német egység meghiúsulásában nagyobb szerepet játszott, mert miután a két német állam vezetése megállapodott egy a szabad választásokat felügyelő nemzetközi bizottság felállitásában, a választások megtartására mégsem került sor a szovjet fél ellenállása miatt. A bizottság 1951 decemberében alakult meg, de munkáját nem kezdhette meg, mert 1952 júliusában az NDK megtagadta tagjainak belépését az országba, melynek hátterében az állt, hogy a Szovjetunió a német újraegyesítés ügyét felhasználva akarta megakadályozni az Európai Védelmi Közösség létrejöttét.

\section{Felhasznált irodalom}

BAUER-KIRSCH, Angela: Zur Legitimation des Bonner Grundgesetzes - Das Selbstverständnis des Parlamentarischen Rates wider die Kritik. Zeitschrift für Politik 2002/2. sz.

DÜWELL, Kurt: Entstehung und Entwicklung der Bundesrepublik Deutschland: (1945-1961). Köln 1981

Eschenburg, Theodor: Das Problem der Neugliederung der deutschen Bundesrepublik: Dargestellt am Beispiel des Südweststaates. Frankfurt am Main 1950

FELDKAMP, Michael F.: Der Parlamentarische Rat und das Grundgesetz für die Bundesrepublik Deutschland 1948 Bis 1949. Option für die europäische Integration und die deutsche Einheit. Berlin/Sankt Augustin 2008

FELDKAMP, Michael F: Der Parlamentarische Rat 1948-1949: Die Entstehung des Grundgesetzes. Göttingen 1998

GÖRTEMAKER, Manfred: Geschichte der Bundesrepublik Deutschland: Von der Gründung bis zur Gegenwart. München 1999

HÜSER, Dietmar: Die Saar-Politik und die deutsch-französische Geschichte an der Grenze - Herausforderungen, Handlungsmargen, ,Frankreichstrategien' in Völkerbunds-, Saarstaats- und frühen Bundeslandzeiten. In: LÜSEBrinK, Hans-Jürgen - POlZIN-HAumann, Claudia - VATTER, Christoph: „Alles Frankreich oder was?” - Die saarländische Frankreichstrategie im europäischen Kontext / 'La France à toutes les sauces?” - La 'Stratégie France' de la Sarre dans le contexte européen: Interdisziplinäre Zugänge und kritische Perspektiven /Approches interdisciplinaires et perspectives critiques. Jahrbuch des Frankreichzentrums. Bielefeld 2017

KRAUS, Elisabeth: Ministerien für das ganze Deutschland? - Der Allierte Kontrollrat und die Frage gesamtdeutscher Zentralverwaltungen. München 1990

LAUfER, Heinz - MÜNCH, Ursula: Das föderative System der Bundesrepublik Deutschland. Opladen 1998 LeHManN, Hans Georg: Deutschland-Chronik 1945 bis 2000. Bonn 2000

MußGNUG, Reinhard: Zustandekommen des Grundgesetzes und Entstehen der Bundesrepublik Deutschland. In: ISENSEE, Josef - KIRCHHOF, Paul: Handbuch des Staatsrechts der Bundesrepublik Deutschland, Band I, Grundlagen von Staat und Verfassung. Heidelberg 1995

SCHWACKE, Peter - STOLZ, Eberhard: Staatsrecht mit Allgemeiner Staatslehre und Verfassungsgeschichte. Köln 1981 VON BEYME, Klaus: Das politische System der Bundesrepublik Deutschland nach der Vereinigung. München 1993 